\title{
The stories African lawyers could tell when analysing legal issues: Lessons for social sciences teachers
}

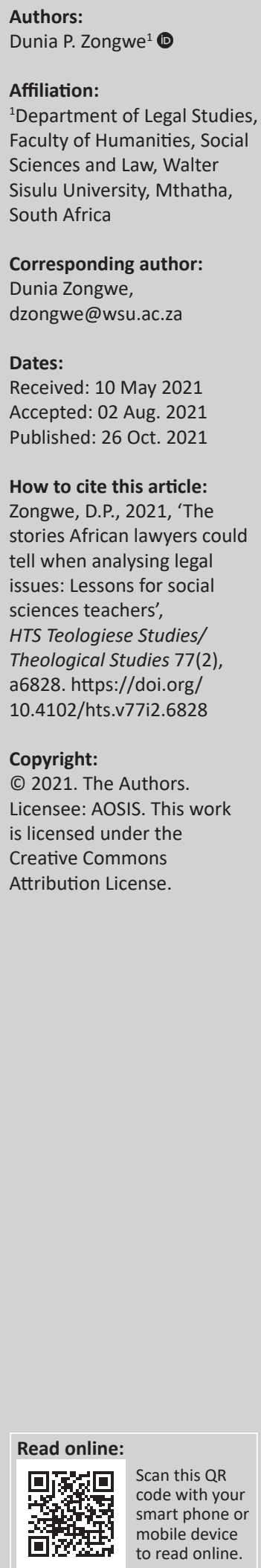

Activists and academics have clamoured for the decolonisation of knowledge, including law. But, unfortunately hardly anyone has put forth strategies for how faculties should decolonise the law. A number of jurists have underscored the necessity to draw on customary laws and traditional values. Still, the \#RhodesMustFall movement has, for the most part, been loud on the outcomes, but quiet on the methodologies. Joining the conversation on the decolonisation of epistemologies, this article contributes to the ongoing efforts to sanitise the law by proposing to revive African oral storytelling cultures as a way to analyse the questions of law facing society. To live up to this task, this article adopts decolonial theory and, through stylised examples, illustrates how lawyers and social scientists in Africa can utilise storytelling to contextualise, (de)construct, and comprehend those questions. This article assumes that lawyers can use African storytelling alongside the prevailing doctrinal method. That method, relaying the coloniality of law and captured by the acronym IRAC (issue(s), rules, application, and conclusion), trains students to approach conflict in society through a highly abstract and decontextualised problem-solving model. Lately, some (Western) social scientists have (re)discovered the practicality of storytelling in presenting analysis and research. However, in African oral traditions, stories worked differently from the manner in which those scientists employ them. African storytelling played a leading role, not only in conveying collective wisdom and social memory from one generation to the next, but also as a medium through which communities transmit the values that hold them together.

Contribution: This article adds to the scholarship on storytelling and narratology by showing how educators can utilise stories to analyse legal questions. That rich scholarship in the humanities and the social sciences has so far not taken seriously the possibility of using stories to analyse research problems. Instead, scholars focus on storytelling mainly as a way of presenting science, not as an analytical tool. This article bridges that gap and demonstrates the analytical value of storytelling.

Keywords: decolonisation of knowledge; decolonial theory; storytelling; Africa; analysis; epistemology; legal education; oral tradition.

\section{Introduction}

For a long time, especially before the 'narrative turn' that occurred in the 1980s (Poletta et al. 2011:112-114), many scholars derided stories and narratives as unscientific. In particular, the African oral stories were regarded as part of the traditional culture, and dismissed as unworthy of being used or deployed as a tool for scientists. Scholars have depicted that oral storytelling tradition as 'pre-literate' (Edosomwan \& Peterson 2016:92-93) and 'premodern' (Hofmeyr 1996:88). By contrast, this article proposes to revive African oral storytelling cultures as a means to analyse problems in society, focusing on legal problems.

For a similarly long time, many scholars from the developing world have looked up to the West for standards for what should qualify as science and as anecdote. Actually, social scientists continue to conduct research in much the same way they did in colonial times. Euro-American scholars produce and publish theories, which are then applied to former colonies (see Connell 2007:44-46; Mamdani 2016:81). The rationality, universality, objectivity, and reliability concepts brandished about by Western scholars have quickly become the standards for determining the truth and mounting truth claims. These concepts also serve to degrade and demean stories as unscientific and non-analytical.

Although campaigns to decolonise epistemologies date back to the liberation movements that led to the independence of former European colonies, the \#RhodesMustFall movement has given this

Note: Special Collection: Social Memory Studies, sub-edited by Christina Landman (University of South Africa) and Sekgothe Mokgoatšana (University of Limpopo). 
crusade new impetus on the African continent. In 2015, students threw human faeces on the statue of Cecil Rhodes at the University of Cape Town, thus rejecting the legacy of this uber-imperialist while clamouring for the decolonisation of knowledge and curricula.

In this article, I propose to revive African oral storytelling cultures to analyse questions of law facing society. To achieve this purpose, I employ decoloniality as a framework. I have accordingly divided my article into four sections. The first one explains decoloniality and how it frames the problem of coloniality of the mind and knowledge. I use those theories to inform and guide my endeavour to revive African oral storytelling cultures to analyse legal problems.

The 'Decoloniality, stories, and epistemologies' section of the article probes the scientific use of analysis. This indispensable aspect of scientific inquiry appears in virtually all academic disciplines. It spreads through the natural sciences and the social sciences. It does not just avail the scientist, it is studied by cognitive psychologists and required for any researcher who wishes to avoid confusion and amalgams. Analysis heavily features in disciplines as varied as economics, physics, medicine, sociology, and law. This article focuses on how people perform analysis in law. In that discipline and profession, analysis tends to comprise issues, rules, application of the rules, and conclusion - a process, famously referred to by its acronym 'IRAC'. The second part also outlines and describes the sorts of problems facing nations, especially those located in the Global South. These include questions of life, health, crime, and economic well-being.

The 'Analysis and questions of law' section concentrates on African oral storytelling cultures. It studies them, and I examine how these cultures could assist in analysing legal problems. Orality characterises storytelling in African traditional cultures. Orality in African communities passes down knowledge, wisdom, rules, and social memory. The medium that transmits this information is the story. In the second half of this section, I turn to the possibilities of using African oral storytelling to analyse legal issues.

The fourth substantive part contains my proposals for reviving African oral storytelling cultures for scientific and analytic purposes. Specifically, this stage of the article reflects on the concrete steps that law faculties and universities can make to incorporate storytelling in their teaching and the curriculum.

At a time when students and scholars across campuses are demanding that universities and governments unshackle them from the yoke of Western epistemological hegemony, researchers have the right - in fact, a duty - to investigate traditional cultures and to redeploy them in contemporary African society. Stories carry the essence of those cultures; hence scholars and jurists ought to look at how social scientists can introduce stories in curricula and in pedagogies within a 'modern' university system inherited from European settlers, the masters of bygone days.

\section{Decoloniality, stories, and epistemologies}

Decoloniality is quite a powerful tool to identify the challenges faced by minority epistemologies. It exposes the methods that Eurocentrism and the project of modernity have used to destroy other, non-Western epistemologies. The Eurocentric myth has 'convinced' people to believe that science has progressed towards a post-colonial world (see Grosfoguel 2007:221), even though the realities of the Global South, marked by gross inequalities (see Connell 2007:212), belie this myth. Western scholars have used concepts of modernity, universality, rationality, and the law to demean, degrade and eventually destroy other epistemologies. African knowledge systems have also suffered from the denigrating and marginalising effects of Eurocentrism.

\section{Decoloniality and science}

Decoloniality stands out for its position that modernity equals coloniality. It addresses matters pertaining to history, society, politics, economy, knowledge, and science. Particularly, De Sousa Santos (1995) picks out the law, alongside power and science, as undergirding the project of modernity. Modern law and modern science have catapulted the coloniality of knowledge (see De Sousa Santos 2002:xvi).

Decolonial theory finds it suspicious that, under the name of 'modernity', people from developing nations are told to accept theories, practices, principles, and rules that deny their experiences, their histories, and their own existence. Modernity/coloniality spun off Eurocentrism as its main knowledge form. Under the guise of modernity, Eurocentrism induces peoples of the Global South to adopt European and Anglo-American values, and to abandon their own as primitive, and rudimentary, if not barbaric. Eurocentrism takes for granted the superiority of European cultures and expects every other culture to follow the European model unilaterally, by force if necessary in what Dussel (1993:217) dubs 'the fallacy of developmentalism'.

The 'modern' university, also known as the 'von Humboldt university', assumes the role of accomplice in entrenching Eurocentrism in former colonies (see Motshabi 2018:108). Nsamenang and Tchombe (2011:7) note that education in most African countries suits more foreign labour markets, rather than the home market, because it offers mainly incoherent chunks of Western knowledges and skills repertoires, instead of dispensing local wisdom and situated intelligences, which agrarian economies need most.

Science did not come to Africa and other regions of the world with European colonisation. By now, a vast body of research proves that scientific knowledge existed in Africa before colonisation, as evidenced, for example, inside the pyramids of ancient Egypt and in the world-renowned Ahmed Baba 
Institute of Higher Islamic Studies and Research in the city of Timbuktu, Mali. To this day, African scholars continue to contribute to expanding that science, although the continent's scientific output pales in comparison to what the rest of the world produces.

Some of the knowledge systems denigrated by colonialism include customary laws and storytelling cultures. Although repugnancy clauses, the settlers treated customary laws as inferior or, in any event, as subject to the 'civilised' laws and norms of the settler communities.

Oral tradition and storytelling practices also suffered a similar fate. Africans were told that this oral tradition belonged to the 'airless space' (Hofmeyr 1996:88) of tradition or the vernacular and that it hindered scientific knowledge and its dissemination. Likewise, stories were considered as lacking the rigour, validity, consistency, and reliability of scientific knowledge.

\section{To decolonise epistemologies through stories}

It is an opportune time for African thinkers to decolonise knowledge. To do so, they have to distinguish the wheat from the chaff, and discard Eurocentric elements from the curriculum when they do not value or assist constituencies in Africa in resolving the problems they confront. Decolonising epistemologies calls for more than just sanitising the curriculum. It demands that law educators place the entire scientific knowledge systems, including notably legal knowledge, on proper foundations. This article hopes to contribute to that task by putting forward ways of incorporating African oral storytelling cultures into the curriculum and the existing pedagogies.

Several thinkers have used stories to decolonise epistemologies. Alimi (2018:132, 137, 140-143, 144) showed that storytelling can serve meaningfully and directly to challenge the formalisation of shari'a. ${ }^{1}$

\section{Analysis and questions of law}

Even for those scholars who accept and embrace stories as enriching the sciences, both natural and social, narratives do not qualify as 'analysis'. For example, although he maintains that stories can effectively challenge the formalisation of shari'a law, Alimi (2018:132) still regards storytelling as 'nonanalytical'. In portraying Islam, he (Alimi 2018:132) opposes the non-analytical forms of human communication, such as storytelling, to the 'discursive tradition', which largely relies on 'analytical discursive argumentation in the public sphere'.

This article departs from the literature on storytelling in science by treating stories, not merely as a tool for presenting science, but mostly as a tool for analysing problems scientifically. Because I argue that African oral stories could help analyse legal problems, a question that spontaneously arises is this: What is 'analysis'?
Analysis involves breaking down a matter, a question, an issue into the elements that constitute it. After breaking material into its constituent elements, analysis relates those elements to one another and to an overall edifice (eds. Anderson et al. 2001:79; Rosenwasser \& Stephen 2015:3).

While investigating the origin of the word 'science', McWhorter (2021:78-80) discovered that it derives from the Ukrainian word skei, which means 'to cut off' or 'to slice'. Latin speakers adopted it as sci, which became the root of the verb 'to know', as one acquired knowledge by cutting up the world in pieces to better understand it (McWhorter 2021:78-80). As Rosenwasser and Stephen (2015:2-3) observe, people analyse all the time; however they do not do so merely to break things down but to construct meanings and understandings of the world they inhabit. This etymology underlines the close relationship between science and analysis. In other words, analysis is a formidable tool at our disposal to manage information and simplify the complexity of life.

\section{What analysis does}

Analysis is all about focusing on a specific facet or a dimension of something. For instance, when an economist looks at unemployment, he or she tends to focus on 'scarcity', whether it relates to the scarcity of job opportunities, education opportunities, or employers. Scarcity thus provides the lens or the prism through which the economist tends to 'analyze' the problem of unemployment. And, ironically, this section of the article analyses... 'analysis'.

If researchers did not analyse, they would have to describe every problem or phenomenon in minute and unnecessary detail. In that sense, analysis is not only useful, but also incredibly efficient.

In law, when sifting through evidence or facts, the analyst typically strives to identify (1) an issue that arise from those facts and (2) the rules that could resolve the issue. Thereafter, the analyst (3) applies those rules to the issue; and, based on that application of the rules to the facts, he or she (4) reaches a conclusion on how to resolve the identified issue. Several law educators refer to this well-publicised analytical process by its mnemonic and acronym IRAC (Finch \& Fafinski 2011:345-346). 'I' stands for 'issue', 'R' stands for 'rules', 'A' stands for 'application', and ' $\mathrm{C}$ ' for 'conclusion'.

Now that I have clarified what analysis entails for scientists and lawyers, what does 'using stories to analyse' signify? The article turns to this central question at once.

\section{Questions of law facing society}

Before they can insert African oral storytelling cultures and practices into the law curriculum, law faculties and lecturers must figure out what they could use those stories for. What kinds of problems society face? And, how can government officials, lawmakers, lawyers, and jurists use the law to resolve those problems? Problems that communities confront 
are myriad, ranging from health, security, employment, crime, and economic welfare.

To ascertain the scope of legally analytical stories, the educator must first determine what the law is. This constitutes an important aspect of the question as to whether stories could serve to analyse questions of law that society grapples with. Coloniality has left a doctrinal legacy, which consists in building arguments by drawing from specified formal sources of authority, including the Constitution, Acts of Parliament, international treaties, the common law, and case law.

The proposition that stories should form part of the arsenal to teach, research, practise, and analyse law may entail incorporating the values of the immediate community into the very definition of the law. Lawyers could then employ stories to channel those values. Conceived in that manner, 'law' would encompass the rules, norms, and values, including values of the community, that regulate the behaviour of the individual in society. This expanded definition features stories implicitly and only as one of the media that convey the values of the community. Nevertheless, I do not claim that decolonising the law will only imply extending its definition to community values. In fact, I leave open the question whether religion could also integrate our general understanding of the law.

The questions of law relate to problems that could be approached through law or resolved by it. Those questions concern disagreements over the meaning of contracts, the behaviour of the government towards citizens, the remuneration of employees, the guilt of a person accused of a wrong against the state, and so forth.

What makes these questions 'legal' resides in the fact that possible answers can be found in rules emanating from certain formal sources, such as the Constitution, Acts of Parliament, and earlier court judgments. The questions of law facing society are, as I have said earlier, countless. What unites them boils down to the presence of rules and principles stemming from formal sources that one could use to resolve those questions. Although I do not rule out the possibility that at least some sorts of stories, could count as formal legal sources, this article mainly focuses on how people could resort to stories to analyse the questions of law that beset society or its members.

\section{African oral storytelling cultures to analyse legal questions}

Africa has built and developed a very rich oral tradition. Through orality, communities across the continent shared wisdom, rules, lessons, knowledge, and social memory. With respect to the latter, stories performed the function of holding communities together by reminding them of the values, the experiences, the victories, the tragedies, and structures that keep them together as a close-knit community with a distinct identity. Likewise, Hofmeyr (1996:88) recognised the 'orderaffirming' ethics of African oral storytelling.
With orality, traditional communities in Africa relayed information through the medium of stories. A story or a narrative is generally understood to be a way of sharing information or knowledge (e.g. see, Tobin \& Snynam 2008). In and of itself, a story is neutral; but its contents give it its identity.

This article posits that story is more than a neutral vessel. It is and becomes a value when certain groups of people prefer to present information in that form rather than other forms of communicating science. Of course, no 'single' story form prevails. In law as in society, the story form varies depending on the story told, the purposes pursued, the audience addressed, and the lesson taught.

\section{Storytelling cultures}

Traditional communities in Africa have developed distinct story forms. Over the decades, they have enriched them and incorporated them in their techniques for passing down information.

The early explorers of the 'dark' continent saw in it a vast, lush jungle inhabited by savages devoid of any culture. To debunk this jaundiced Eurocentric visions of the continent, Achebe (1958) in Things Fall Apart utilised proverbs and storytelling to showcase Africa's rich culture. Through story, he supplied his audience with information about life and culture in African societies before the Europeans invaded the continent. Achebe's attitude rekindled interest in the storytelling tradition (Edosomwan \& Peterson 2016:94ff).

The fact that the story form prominently features the cultures of the communities where people widely use them has farreaching implications. Firstly, seen from this perspective, stories become protected by the right to culture (see also Nsamenang \& Tchombe 2011:9), and the right to practice one's customary laws. Secondly and perhaps more importantly, this insight means that stories become something that decolonial scholars and law educators must absolutely revive and reinstate in the positions they used to occupy in the communities in which people employed them.

\section{Storytelling as science}

Contrary to what many scientists would have us believe, storytelling is scientific. It is scientific in the sense that scientists could use them to share information. Storytelling serves to teach children and adults alike (Edosomwan \& Peterson 2016:91-92). It simulates (i.e. gives people knowledge about how to act) and inspires (i.e., motivates people to act) (Heath \& Heath 2010:206). Scientists could also narrate stories to fulfill other purposes, depending on the contexts of their telling. The variety of story forms reveals that it is quite a malleable, flexible instrument that people can use to cater to different scientific audiences.

In the past few decades, many scientists and scholars have acknowledged the scientific nature that some sorts of 
storytelling have. Since the 'narrative turn' that took place in the 1980s, social scientists have started to emphasise the centrality of stories to cognition (see Poletta et al. 2011:112-114). Stone-Mediatore (2015) examines propositions in feminist theories that experience-based narratives enable more rigorous and inclusive discussions on matters affecting citizens and scholarly research.

\section{Storytelling cultures}

Still, no one single storytelling culture dominates in Africa, just like no one single African identity exists, considering the sheer cultural variety of peoples on the continent. Africa and its many communities have evolved a myriad of storytelling types. What connects them is not their forms, but the values that they tend to convey. Indeed, from both a philosophical and cultural perspective, African storytelling tends to purvey values related to Ubuntu or resembling it, such as Hunhu (Zimbabwe), OmUuntu (Namibia), and uMunthu (Malawi). These values comprise harmony, reconciliation, diversity, humanity, and participation.

\section{African orality}

Orality in Africa differs from orality in other corners of the globe. However, people know little about African oral, unwritten tradition, especially in the Western societies, which stresses the idea of literacy and the written word (see Finnegan 2012:3). After all, oral literature remains marginalised (Hofmeyr 1996:88-89).

\section{Oral literature in Africa}

Like most oral literature, African oral storytelling depends (1) on a performer (i.e. a speaker, an actor, a singer, or a dancer) expressing it in words on a given occasion (performance); (2) on improvisation, verbal variety, or original composition (originality); and (3) on a participating audience (Finnegan 2012:4-14).

African orality differs from its counterparts by its musicality. In societies, such as those found in traditional Western African communities, the storyteller is a singer, a poet, or more precisely - a 'griot'. The storyteller would sing his stories the way that a singer sings his songs. The songs would work like mnemonics as they help listeners and audiences remember the lyrics or the contents that the stories contain.

Moreover, orality in traditional Africa meant that the word is not just the vehicle. It also constitutes the message, and, most importantly, performance. Saying something does not just convey information; it brings about certain events, good or evil, blessing or curse.

\section{The story, African-ness and oral tradition}

To distinguish the African-ness in the oral tradition found in communities on the continent, I must first define a 'story'. Without such definition, social scientists will find it nearly impossible to tell stories from other ways of communicating scientific information.
I found Schimel's rendering quite handy. He defines a story by its structure. Thus, for Schimel (2012:26-27), the four elements that underlie the structure of all stories, including those that scientists write, comprise an opening, a challenge to overcome, actions taken to overcome the challenge, and the resolution of that challenge. He (Schimel 2012:27) sums up these elements in the acronym 'OCAR', which stands for opening, challenge, action, and resolution. In the next section of this article, I illustrate the OCAR tactic and relate it to the analysis of dilemmas in law.

The African-ness in the oral storytelling cultures that I advocate comes from the values and the modes of delivering them. As I have said earlier, the stories do not only convey knowledge, but also reflect the storyteller's identity. Those stories are imbued with the values, norms, and knowledge, espoused by the storyteller, primarily Ubuntu. Referring to Nigerian traditional communities, Edosomwan and Peterson (2016:92) remarked that stories 'preserved the identity of the people'.

African orality stands apart from the other types of orality because African orality is musical. It imparts knowledge but also entertains its audiences. For that reason, it functions as a powerful tool to make learning memorable, especially because it also features proverbs and other mnemonic devices that help both individual and collective memory (see also Avoseh 2013:240). Because of that, law teachers can use storytelling to both decolonise the law and legal education, and - above all - ensure that learners absorb the story-told lessons effectively.

\section{Proposal to revive legally analytical storytelling cultures}

In this section of the article, I put forward my recommendations for reviving African oral storytelling cultures to analyse legal problems. Ultimately, I hope that these legally analytical stories will help decolonise the law and the law curriculum, and to free the learning mind from the Eurocentrism that pervades legal education on the continent.

\section{Using African oral storytelling cultures to analyse legal questions}

I propose the deployment of African oral storytelling cultures to analyse legal questions by restructuring the IRAC. Instead of IRAC, I propose ICRAC. Here, 'I' stands for 'issue', 'C' for 'community', ' $\mathrm{R}$ ' for rules, 'A' for 'application' of the rules to the facts, and ' $\mathrm{C}$ ' for both 'conclusion' and 'community'.

Thus, from a structural vantage point, I invite educators to teach and analyse legal questions by elevating the community in mediating issues and rules, and then in mediating the application of the rules to the facts and the conclusion drawn from such application. This invitation does not imply establishing a jury system, which concerns court procedure. Rather, my proposal addresses itself solely to cognition, and not to court practice. 
Nonetheless, I must stress that my proposal only re-organises the IRAC. Re-arranging the IRAC method does not guarantee that the revamped analysis will assume a story form. To bestow a story form on the analysis, the analyst would need to implement the OCAR model or any other model for effectively presenting information in story form.

An example would suffice. The traditional IRAC analytical model would seek to resolve an accusation of murder by first identifying whether the facts give rise to a reasonable suspicion of murder. Then, the lawyer would seek to find out what the formal sources of law provide for to define and punish murder. Here, the lawyer would understand that the common law defines 'murder' as an act that is intentionally and unlawfully causing the death of another human being who was alive at the time of the conduct in question. Applying the rules to the facts, the lawyer would observe that the accused (' $X$ ') caused the death of the victim (' $Y$ ') by shooting at the victim. Based on such observation, the lawyer would, lastly, conclude that $\mathrm{X}$ is guilty of murder.

By contrast, the storytelling lawyer would use a technique that combines ICRAC and a powerful story-structuring formula, such as Schimel's OCAR. Starting with ICRAC, the lawyer would first seek to single out the facts that create a reasonable suspicion of murder. Then, before defining this crime, the lawyer would reflect on how the crime of murder affects the community and why the community insists on criminalising that crime. Only then, will the lawyer define the crime and recite the rules that govern it and its punishment. The lawyer will move on to apply those rules to the facts, noting that taking one's life constitutes an act that the community frowns upon because of the human(e)ness embedded in the community's outlook on life and worldviews, and the community's views of the continuity between the individual and the cosmos. Building on such perspectives, the lawyer would conclude that $X$ murdered $Y$ and that community demands a harsh punishment as murder offends one of the community's core values.

In presenting that information, the storytelling lawyer must make sure that it takes on the OCAR form or similar forms. The lawyer would begin his presentation with an opening, which can feature an anecdote, a startling fact, statistics, a historical background. The lawyer could be creative or imaginative here. Then the lawyer would disclose the challenge, which would consist in determining whether there is a basis to suspect that $\mathrm{X}$ committed murder and what such challenge represent for the community. The lawyer would proceed to recite the definition and the rules that apply to murder. Next, the lawyer would apply the definition and those rules to the facts, underscoring which values this offense hurts the community and how it tears apart people in that community. By virtue of such application of the rules, the lawyer would not merely say that $X$ is guilty of murdering Y. Instead, he would suggest ways of how the community can resolve and come to grips with such deviance (i.e., murder), and heal the body politic. The basic idea boils down to embedding the story in the fabric and norms of the community.

\section{Encouraging law faculties to tell and teach stories}

Another recommendation to revive storytelling cultures is that the country's higher education regulator, such as the Council on Higher Education (CHE) in South Africa, strongly encourages law faculties to use stories as one of the methods for teaching and analysing the law. At this juncture, I want to urge those regulators to guard against obliging law faculties to adopt such pedagogies. While the virtues of storytelling speak for themselves, law faculties and lecturers should not be pressured or feel pressured to adopt such pedagogical philosophy. Doing so would turn the emancipatory potential of storytelling into another form of hegemony — the very thing that decoloniality fights against.

The third recommendation prompts law faculties to train and upskill their lecturers so that they can tell stories in general and stories in the African way. Whether they should use stories in class is a question best left to lecturers themselves. But law faculties should consider it an imperative to make sure that, should they desire to do so, lecturers will know how to analyse law through stories and how to teach storytelling to their students.

\section{Keeping storytelling alive}

In addition to the three proposals mentioned above, jurists and decolonial scholars should keep alive the conversation about the practicality of stories, including conversations about the place of digital technologies in telling personal and indigenous stories in Africa. This is because this article does not exhaust all the manner in which law educators and future lawyers can leverage stories for their professional goals. Indeed, there are other ways - apart from combining entertainment, persuasion, and information — in which they can harness stories. Educators can teach through entertaining stories, as long as they remember that information and persuasion should remain the top priorities in teaching and analysing law. Entertainment plays a crucial, although secondary, role because it strengthens the learning process and ensures that teachers inculcate effectively and that learners assimilate just as effectively.

\section{A caveat about importing or adapting Western education}

In advising law faculties to adapt Schimel's OCAR technique and the traditional IRAC paradigm, I acknowledge that some readers may object that such adaptation reinforces Eurocentrism on the brown continent. As Nsamenang and Tchombe (2011:8) lament, pedagogies in Africa over-rely on imported knowledge from the industrialised societies of Europe and America. These critics could justifiably remark that, in all likelihood, Schimel never bore Africans in mind when he designed his technique.

However, readers should view the strategy that I advocate as one first, giant step in a long march towards the comingof-age of African pedagogies. Other reasons explain why 
decolonial legal scholars must treat carefully when overhauling legal education. Firstly, law's inherent conservatism impedes the kind of quick, revolutionary changes that, in a perfect world, a decolonisation campaign would accomplish. Secondly, an abrupt delinking of African universities from the education architecture that they have carried over into their post-independence polities would foreclose opportunities for their graduates to further their studies, exchange with non-Africans, or market their skills outside of Africa. Thirdly, instead of trying to reinvent the wheel, reformists would act more efficiently by filtering out the retrograde elements of the imported Western education while retaining the most relevant elements.

Of special importance, my story-as-analysis thesis flows from the premise and the caveat that decolonisation should never amount to retreating into one's shell. My stance on decoloniality affirms the right of developing nations to free the mind of their people and, in doing so, to continue dialogue with other cultures, from both the Western metropolises and the knowledge sites of the Global South. The likes of Barreto (2018) describe decolonial thought as a dialogue between Eurocentrism and Third World epistemologies. NdlovuGatsheni (2021:93) calls on stakeholders to convert universities into 'pluriversities' where diverse voices, mosaic epistemology, and intercultural translation flourish. In the same vein, my decolonial stance promotes entering into dialogues with other cultures, thereby pluralising standpoints.

\section{Conclusion}

In this article, I have pleaded that, to decolonise the law and the mind of law students, universities and law faculties should encourage lecturers to teach and analyse the law through stories. I have maintained that lecturers should apply African oral storytelling cultures to analyse legal questions.

This plea arises against the background of the \#RhodesMustFall movement - a movement that cried for the decolonisation of knowledge in South African universities. This movement speaks to students not only on South African campuses, but to African law students around the continent as well. In fact, this is a call to arms for the law student in the developing world.

To attain this goal, this article has taken advantage of decolonial theories, which underline the nexus between modernity and coloniality. It recalls that the 'modern' university has been a site for perpetuating the coloniality of knowledge, under the guise of universality, rationality, 'modernity', civilisation, and objectivity. This is not to say that African knowledge systems lack those qualities, but that those qualities are not neutral; they are socially (re) constructed to proselytise Western norms by making them look superior. In the process, these norms denigrate, devalue and destroy non-Western epistemologies.

To decolonise the law and legal education, several initiatives become necessary. I contribute to this debate by arguing that law students - the lawyers of the future - should analyse legal problems through stories, the traditionally African way. In that manner, lawyers will learn the skills of approaching legal questions in a way that seem 'natural' or 'intuitive' to them but also in a way that would speak to the norms and values of the community in which they advance their arguments.

Decolonial theorists still have a long road ahead of them before African law and the mind of the African law student can be fully decolonised. For instance, jurists will have to investigate matters, such as the role of religion, customary laws, and Ubuntu, in the legal system. But this is a debate for another day. For now, I rest my case that law teachers must analyse and argue their positions through stories.

\section{Acknowledgements}

The author acknowledges Tanya Pieterse.

\section{Competing interests}

The author declares that he has no financial or personal relationships that may have inappropriately influenced him in writing this article.

\section{Author's contributions}

D.P.Z. is the sole author of this article.

\section{Ethical considerations}

This article followed all ethical standards for research without direct contact with human or animal subjects.

\section{Funding information}

This research received no specific grant from any funding agency in the public, commercial or not-for-profit sectors.

\section{Data availability}

Data sharing is not applicable to this article as no new data were created or analysed in this study.

\section{Disclaimer}

The views and opinions expressed in this article are those of the author and do not necessarily reflect the official policy or position of any affiliated agency of the author.

\section{References}

Achebe, C., 1958, Things fall apart, William Heinemann, Portsmouth.

Alimi, M.Y., 2018, 'Muslims through storytelling: Islamic law, culture and reasoning in South Sulawesi', Komunitas: International Journal of Indonesian Society and Culture 10(1), 131-146. https://doi.org/10.15294/komunitas.v10i2.16269

Anderson, L.W., Krathwohl, D.R., Airasian, P.W., Cruikshank, K.A., Mayer, R.E., Pintrich, P.R. et al. (eds.), 2001, A taxonomy for learning, teaching, and assessing: A revision of Bloom's taxonomy of educational objectives, abridged edn., Addison Wesley Longman, New York, NY.

Avoseh, M.B.M., 2013, 'Proverbs as theoretical frameworks for lifelong learning in indigenous African education', Adult Education Quarterly 63(3), 236-250. https:// doi.org/10.1177/0741713612462601 
Barreto, J.-M., 2018, 'Decolonial thinking and the quest for decolonising human rights', Asian Journal of Social Science 46(4-5), 484-502. https://doi. org/10.1163/15685314-04604006

Connell, R., 2007, Southern theory: The global dynamics of knowledge in social science, Polity Press, Cambridge.

De Sousa Santos, B., 1995, Toward a new common sense: Law, science, and politics in the paradigmatic transition, Routledge, London.

De Sousa Santos, B., 2002, Toward a new legal common sense: Law, globalization and emancipation, 2nd edn., Cambridge University Press, Cambridge.

Dussel, E., 1993, 'Eurocentrism and modernity (Introduction to the Frankfurt lectures)', Boundary 2 20(3), 65-76. https://doi.org/10.2307/303341

Edosomwan, S. \& Peterson, C.M., 2016, 'A history of oral and written storytelling in Nigeria', paper presented at the American Association for Adult and Continuing Education (AAACE) Commission for International Adult Education (CIAE) Annual Pre-Conference (65th, Albuquerque, NM), 6-8th November.

Finch, E. \& Fafinski, S., 2011, Legal skills, 3rd edn., Oxford University Press, New York, NY.

Finnegan, R., 2012, Oral literature in Africa, Open Book Publishers, Cambridge.

Grosfoguel, R., 2007, 'The epistemic decolonial turn: Beyond political-economy paradigms', Cultural Studies 21(2-3), 211-223. https://doi.org/10.1080/ 09502380601162514

Heath, C. \& Heath, D., 2010, Made to stick: Why some ideas survive and others die, Random House, New York, NY.

Hofmeyr, I., 1996 'Not the magic talisman: Rethinking oral literature in South Africa', World Literature Today 70(1), 88-92. https://doi.org/10.2307/40151859
Mamdani, M., 2016, 'Between the public intellectual and the scholar: Decolonization and some post-independence initiatives in African higher education', Inter-Asia Cultural Studies 17(1), 68-83. https://doi.org/10.1080/14649373.2016.1140260

McWhorter, J., 2021, Nine nasty words: English in the gutter - Then, now, and forever, Avery/Penguin Random House, New York, NY.

Motshabi, K.B., 2018, 'Decolonising the university: A law perspective', Strategic Review for Southern Africa 40(1), 104-115. https://doi.org/10.35293/srsa.v40i1.277

Ndlovu-Gatsheni, S.J., 2021, 'Internationalisation of higher education for pluriversity: A decolonial reflection', Journal of the British Academy 9(1), 77-98. https://doi. A decolonial reflection', Journa
org/10.5871/jba/009s1.077

Nsamenang, A.B. \& Tchombe, T.M.S., 2011, 'Introduction: Generative pedagogy in the context of all cultures can contribute scientific knowledge of universal value', in A.B. Nsamenang \& T.M.S. Tchombe (eds.), Handbook of African educational theories and practices: A generative teacher education curriculum, pp. 5-19, theories and practices: A generative teacher education
Human Development Resource Centre (HDRC), Bamenda.

Poletta, F., Chen, P.C.B., Gardner, B.G. \& Motes, A., 2011, 'The sociology of storytelling', Annual Review of Sociology 37, 109-130. https://doi.org/10.1146/annurevsoc-081309-150106

Rosenwasser, D. \& Stephen, J., 2015, Writing analytically, 7th edn., Cengage Learning Stamford.

Schimel, J., 2012, Writing science: How to write papers that get cited and proposals that get funded, Oxford University Press, New York, NY.

Stone-Mediatore, S., 2015, 'Storytelling/narrative', in L. Disch \& M. Hawkesworth (eds.) The Oxford handbook of feminist theory, pp. 934-953, Oxford University Press, Oxford.

Tobin, P.K.J. \& Snyman, R., 2008, 'Once upon a time in Africa: A case study of storytelling for knowledge sharing', Aslib Proceedings 60(2), 130-142. https://doi. org/10.1108/00012530810862464 